\title{
Intercultural Competence Development of German Nursing Personnel via Advanced Training Projects
}

\author{
Natalya Bidyuk \\ Khmelnytskyi National Univesity \\ Khmelnytskyi, Ukraine \\ http://orcid.org/0000-0002-6607-8228 \\ Halyna Oleskova \\ Khmelnytskyi National Univesity \\ Khmelnytskyi, Ukraine \\ https://orcid.org/0000-0003-2011-8068 \\ Vitaliy Tretko \\ Khmelnytskyi National Univesity \\ Khmelnytskyi, Ukraine \\ https:// orcid.org/0000-0003-3608-1378
}

\begin{abstract}
This paper describes the advanced training projects to develop the intercultural competence of German nursing personnel. There are many German projects, which promote the development of intercultural competence and other professional competences of doctors and nursing personnel. Within this paper, the authors analyzed the following projects: "Migrants in Geriatric Nursing" (MigA project), "German Professional Language in the Geriatric Nursing" (FaDA Projekt), "Intercultural Open Nursing Service AWO in Ulm", "Interprofessional and intercultural activities in the area of medicine, nursing and social services" (IPIKA project), IPIKA Plus project, "MIG-COMM-EU Multilingual Intercultural Business Communication for Europe" (MIGCOMM-EU project), "Intercultural Medical Communication in Europe" (IMED-KOMM-EU project). The authors have paid much attention to the significance of the concept of intercultural competence in nursing care. Besides, the article highlights the issue of the increase in the number of people with a migrant background in Germany. This study also provides another perspective on the advanced training projects for intercultural competence development of German nursing personnel.
\end{abstract}

Keywords: advanced training projects; culturally sensitive care; intercultural competence; migrant background; German nursing personnel 


\section{Introduction}

Nowadays, humanity faces new challenges due to globalization processes. One of the issues that need a decent solution is the migration issue. The reasons that make people leave their own homes and seek better luck in another country may be different, but one thing remains common: these people have to adapt in the new environment, and the society in which they must react in a certain way to such changes. This problem has not passed over Germany too. According to the Federal Statistical Office (Statistische Bundesamt), the number of people with a migrant background in Germany increased by 4.4 percent in 2018 compared to last year and amounted to 19.3 million. A person is considered in Germany to have a migrant background if she personally or her parents were not born with a German nationality. Currently, about a quarter of the population of Germany (23.6 percent) has a migrant background (Welt Digitale Zeitung, 2018). According to the new "German Nursing Professions Act" ("Pflegeberufegesetz" vom 17.07.2017) of 17 July 2017, part II, article 1, §5, "the training of skilled nursing professionals promotes the development of the necessary professional and personal competences for independent, comprehensive and processoriented care for people of all ages in acute and permanent inpatient and outpatient settings, as well as basic methodical, social, intercultural, communicative and educational competences, including the abilities of knowledge transfer and self-reflection. Meanwhile, lifelong learning is a process of professional growth of a person understood, as a signaficant continuous personal and professional development recognized" (Bundesgesetzblatt, 2017; Pflegeberufegesetz, 2017). The purpose of the study is to provide a general overview of advanced projects, which are used to develop the intercultural competence of nursing personnel in Germany. The sense and significance of the concept of intercultural competence in nursing care we are going to reveal here.

\section{Literature Review}

The proper understanding of the intercultural competence development of German nursing personnel is impossible without a comprehensive overview of the notion of the concepts of intercultural nursing, intercultural competence, cross-cultural nursing, cross-cultural competence, transcultural nursing as well as transcultural competence in nursing care. While researching we have taken into account various scientific resources. Scholars should select manuscripts that are to be involved in the theoretical framework of the study extremely carefully since its success depends on the originality and authenticity of these chosen ones. We have considered the works of many outstanding scholars, mostly German, as they were first to cover the problems of intercultural competence and its development in nursing personnel. Thus, theoretical framework of our study is based on works by scholars such as Behrens (2011) (fundamental considerations in the intercultural opening in healthcare), Domenig $(2001,2007)$ (transcultural nursing and transcultural competence), Flechsig (2000) (transcultural learning), Friebe and Zalucki (2003) (intercultural education in nursing), Habermann and Stagge (2015) (people with a migrant background in professional nursing), Hellige and Michaelis (2005) (culture-sensitive care in geriatric nursing), Hundenborn, Heuel, Zwicker-Pelzer, Fendi, Kühn-Hempe, Mausolf and Scholl (2018) (approaches to cultural sensitivity in healthcare, 
competence-oriented, science-based and multi-professional education, advanced and further training), Ilkilic (2017) (the phenomenon of intercultural competence as a key qualification), Kiel (1996) (transcultural competence), Oldenburger (2010) (intercultural team \& culture-sensitive care in geriatric nursing), Orque (1983) (approach to the theory of nursing), Plunkte (2017) (some aspects of communication with patients from other cultures) Reinhardt (2009) (intercultural competence in nursing), Rommelspacher (2005) (transcultural advice in nursing), Uzarewicz (2001, 2002) (foundations of professional transcultural nursing), Visser (2002), Welk (2017) \& Zanier (2016) (some aspects of culturally sensitive care, process of forming cultural sensitivity in healthcare), von Bose \& Terpstra (2012) (caring for muslim patients).

Professional training of nursing personnel in Germany promotes the acquisition of the necessary competences, but nowadays, the possession of intercultural competence is vital. Intercultural competence in nursing and its implementation in education is multifaceted and includes social, ethnological, political, and pedagogical aspects (Reinhardt \& Sahmel, 2009, p. 136). We agree that "intercultural competence is the ability to act effectively and properly in intercultural situations; and certain views, emotional aspects, intercultural knowledge, special skills, and general reflexive competence contribute to intercultural competence development" (Bertelsmann \& Fondazione, 2008). Intercultural competence is not considered to be isolated from professional requirements, and therefore it cannot be narrowed to the skills of interaction and communication. In terms of intercultural competence requirements to a person are defined in a professional context by the demands of professional practice (Reinhardt \& Sahmel, 2009, p. 144). As part of the health professionals training, the concept of "intercultural competence" should be understood as skills and abilities that help to overcome potential conflicts and facilitate understanding of their origin in an intercultural context, thus providing an orientation of action based on ethics and needs (Ilkilic, 2017).

Aspects of intercultural competence are readiness: firstly, to accept people of different regimes, behavior, ways of communication; secondly, to reflect on their own feelings, models of thinking and reactions; thirdly, to be open to foreign cultural models; fourthly, to be interested in other cultures or cultural imprints; fifthly, to be aware and, possibly, to acquire language knowledge; sixthly, adapt to the peculiarities of communication; seventhly, to the interaction of I-You (orientation towards personality and lack of restrictions on religion, culture or nation); eighthly, to focus on constructive mental devices (the concept of "Double Victory"); ninthly, to cooperate and coordinate conflicts of interests and needs and compromise. In the area of nursing, there are two concepts (cultural sensitivity and culturally sensitive care) in connection with intercultural competence. The idea of cultural sensitivity relates to the ability to be sensitive to perception, thinking, behavior, and communication with people from other cultural environments. Several authors, such as G. Hundenborn, G. Heuel, R. Zwicker-Pelzer, S. Fendi, C. Kühn-Hempe, K. Mausolf, H. Scholl paid attention to cultural sensitivity at their module handbook, dedicated to the project "Cultural sensitivity in healthcare". Now, cultural sensitivity includes 
the following skills: firstly, the reflection of their personal cultural reflections in thinking, feelings, and actions; secondly, the adoption of other cultural influences on behavior as equivalent to their models of life; thirdly, obtaining knowledge about possible forms of thinking, emotional reactions, and behavior of people from other cultures;fourthly, the attempt of empathy in the ways of thinking, feeling and actions of people with different cultural backgrounds; fifthly, the filtration of similarity/community, as well as contradictions and differences, in order to develop the starting points for a common strategy of action (Berufs-Ausbildungs-Zentrum e.V. Selbelang, 2019; Hundenborn et al., 2018).

Culturally sensitive care aims at ensuring that the person in need of nursing care can live according to the individual values, cultural and religious characteristics, and needs despite restrictive conditions (e.g., home care and nursing personnel with different cultural backgrounds, etc.). It responds to the individual needs of patients, and not only the ability to cure and treat him or her, like everyone else. Therefore, culturally sensitive care also means an individual or subject-oriented care. It sees the patient primarily not only a person in need of nursing care but an individual in his lifeworld (every health worker also wants to be perceived and appreciated as a person, not just as an employee of the institution). It is based on nursing intercourse every time, again on the current situation and needs of the patient. Nursing personnel introduces themselves to interaction as a person. It reflects and respects its borders and accepts the opponent. Implementation of such nursing care is impossible without the intercultural communication of patients and medical personnel (Berufs-AusbildungsZentrum e.V. Selbelang, 2019).

Plunkte (2017) thinks that culturally sensitive care can be achieved if the subject of intercultural competence is increasingly implemented in education and training. "To develop culturally sensitive patient care change and development processes are required at several levels, and must involve all parties concerned" (Plunkte, 2017). The work "People with a migrant background in professional nursing" of Habermann and Stagge (2015), mentioned that "nowadays the attraction of people with a migrant background to professional nursing practice in Germany became already a reality" and it will be even more significant in the future because of the recruitment efforts of professional nursing personnel from abroad (Habermann \& Stagge, 2015, p. 15). The concept of the intercultural opening is transferred to the medical care facilities and illustrated using the example of Bad Oeynhausen Clinic in the work "Intercultural opening in healthcare. Overview - strategy - practice" by Behrens (2011). With the help of a qualitative research approach, the concrete implementation of the concept in Bad Oeynhausen is examined. Besides, the concepts of the migrant background and the culturally sensitive projects are mentioned in this work (Behrens, 2011). 
In the chapter "Intercultural competence in nursing" in the book of Reinhardt and Sahmel (2009), "Promote nursing competences" gives prominent coverage to the issue of intercultural competence of nursing personnel. The author points out that "considering the group of foreigners, such terms as migrants, immigrants, settlers, resettlers or refugees are clearly differentiated." The EU's internal migrants are citizens of the European Union enjoying exclusive rights as EU citizens. Spouses and family members of third-country nationals are spouses, children, and possibly also other family members who, under certain conditions, can enter or join the family unions. Refugees and asylum seekers have a right to asylum in Germany under Article 16a of the Basic Law. Contractual seasonal workers and other temporary migrant workers from non-EU countries are workers recruited from abroad and work temporarily in Germany. International students travel to Germany to study at the university (Reinhardt \& Sahmel, 2009, pp. 137-138).

In the research "Intercultural competence as a key qualification for healthcare professionals" of Ilkilic (2017), defines the intercultural competence of healthcare professionals in Germany and reveals its significance nowadays. It consists of intercultural communication, general knowledge about different cultures, avoiding stereotypes, and tolerance. Medical education in Germany concentrates on treating patients with specific diseases. The fact that these patients might have a different cultural background is rarely discussed, although intercultural misunderstandings can influence the outcome of health interventions considerably. Such an amount and heterogeneity of groups arriving in Germany require a competent and individual approach to nursing care. The question of how to set up a culturally sensitive and needs-based medical care for people with a migrant background includes many aspects, including the implementation of relevant education, training and continuing education of healthcare professionals (Ilkilic, 2017, p. 24).

\section{Methodology}

First of all, a scientific literature review on the problem under study was used in the research. We processed the accumulated data via the methods of analysis and synthesis, hermeneutic interpretation and searching, deduction and induction, individualization, generalization, systematization, and presented our findings within the scope of this paper. Moreover, we have conducted a theoretical analysis of data contained in the scientific sources.

\section{Findings and Discussion}

There are many German projects, which promote the development of intercultural competence and other professional competences of doctors and nursing personnel such as "Migrants in Geriatric Nursing", "German Professional Language in the Geriatric Nursing", "Intercultural Open Nursing Service AWO in Ulm", "Interprofessional and intercultural activities in the area of medicine, nursing and social services", "IPIKA Plus project", "MIG-COMMEU - Multilingual Intercultural Business Communication for Europe", "Intercultural Medical Communication in Europe", etc. 
Let us consider in more detail the project, "Migrants in Geriatric Nursing" (Migrantinnen und Migranten in der Altenpflege). The duration of this project was from November 2004 to October 2006. Jürgensen (2015) in her Master's thesis "Language support for foreign nurses: Design elements for course design in nursing education" revealed that "because of the relatively high proportion of foreign nursing personnel working in the area of geriatric nursing", more than ten years ago it was decided to create qualification programs to improve language proficiency. Thus, in North Rhine-Westphalia and Bavaria, for example, which has a relatively high share of foreign nursing personnel, two well-documented projects were carried out, in which nursing personnel with a migration background increased its qualifications. In the MigA project, the German Institute for Adult Education first identified the need for qualifications and, in particular, the need for language support of migrants working in 97 permanent and 16 ambulatory institutions in North Rhine-Westphalia. In order to be able to develop an address-oriented and activity-oriented program, both management institutions and participants were asked about their language needs. Course modules were designed in such a way that actual content and authentic conversational situations were related to their use of words, linguistic intentions, and their context". The content of the four core modules content was based on the requirements of the "Social Long-Term Care Insurance Act" ("Pflegeversicherungsgesetz" vom 26.05.1994), quality standards and current discourses of nursing science and gerontology. Modules "Communicating with residents, collecting information", "Planning and Caring", "Nursing Documentation and Nursing Personnel Report", and "Discussion of a Clinical Case in a Multicultural Nursing Team" consisted of four hours during four training sessions. At the end of each refresher course, lists of relevant words and grammar rules were made, interviews were analyzed using interviews, and linguistic reflections were practiced. The modules are comprehensively presented in the guide "Migrants in Geriatric Nursing", along with educational materials and methodological guidelines (Jürgensen, 2015, pp. 37-38).

Friebe (2006) described this project, notes in his work "Migrants in geriatric nursing" that "the concept of linguistic and intercultural support for immigrant carers with a migrant background should take into account numerous levels of learning and action". "Therefore, the comprehensive qualifications' concept contains at least three elements: firstly, individual educational activities (selfstudying with media, German as a foreign language), on-the-job-training (support through placement supervision, educational tandems, discussion), inhouse learning (addressee-specific and intercultural advanced training)" (Friebe, 2006, p. 55).

Our attention deserves consideration of the project, "German Professional Language in the Geriatric Nursing" (Fachsprache Deutsch in der Altenpflege) as an example of specialized German language courses for geriatric nursing personnel with a migrant background who worked in stationary charitable institutions AWO (Arbeiterwohlfahrt). The duration of the project was from May 2011 to April 2014. It contained eight training modules of 100 hours. The modules were developed on the basis of the assessment of language needs in 
inpatient geriatric care. Besides, they were thematically related to the tasks and fields of activity in the area of geriatric nursing, namely: production and work processes, multicultural personnel, nursing and support of residents in everyday life, nursing care and help in treatment, cooperation with relatives, cooperation with external actors, quality assurance, self-service (AWO Bundesverband e.V., 2014).

Just as in the MigA project, language requirements were determined in advance. It was based on the various interaction settings in the nursing practice and took a "multi-perspective needs analysis" before. The learners' individual linguistic needs were stemmed from their expectations and motives, from which they participated in the educational activity. It also focused on personal study habits and subjectively perceived deficits. As a result, the AWO was able to establish that nurses have to cope with highly complex linguistic requirements in their daily work with different participants. Communication in nursing thus takes place firstly, with various communication partners; secondly, on different levels of relationship; thirdly, in different technical languages or codes; fourthly, on different communication channels; fifthly, at different language levels. On this basis, the AWO has developed the above-mentioned modules that correspond to eight professional areas of nursing, e.g., "Nursing care for residents" or "Cooperation with external actors". Nurses act in these areas of action from various professional roles, e.g., as a member of the team, as a reference person for residents or as responsible for quality assurance. Depending on their role and function, they are entrusted with different tasks that require appropriate communicative and intercultural skills. To this end, the AWO has developed a matrix in which the professional situation with the role of the employee and his tasks as well as the required competences, are depicted (Jürgensen, 2015, pp. 3839).

Let us turn our attention to a more detailed model project, "Intercultural Open Nursing Service AWO in Ulm" (Interkulturell geöffneter Pflegedienst der AWO in Ulm). Currently, 26 percent of all residents of Ulm over 65 have a migration background. The target group of the intercultural open outpatient nursing service is senior immigrants from different social groups. The purpose of this project was to open an existing outpatient nursing service for representatives of diverse cultures in 2014 and 2015. For intercultural open nursing services, it is essential that their employees have professional intercultural competences.

It was necessary to take various measures to ensure that the nursing personnel became an intercultural competence team. In the question "What is professional intercultural competence, or what does it do?", the project participants were guided by Benner's novice-to-expert competence model (Figure 1), according to which nursing personnel professionally grows through its professional activities from beginners to nursing experts (Pflegeexperten). Within the framework of this project, was considered the issue of qualification improvement of nursing personnel to obtain professional intercultural competence (Fortbildungen zur Erlangung von Interkultureller Handlungskompetenz) (Figure 2). 


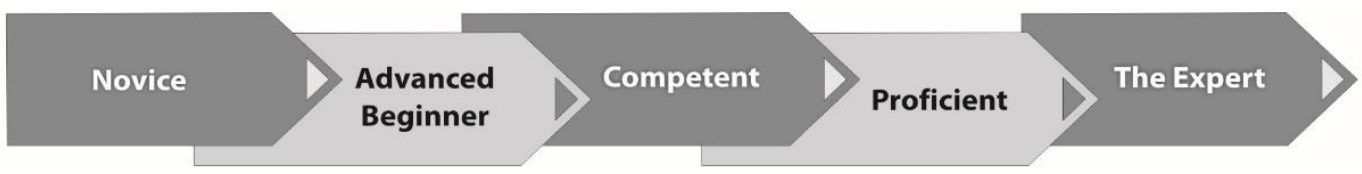

Figure 1: Benner's Stages of Clinical Competence.

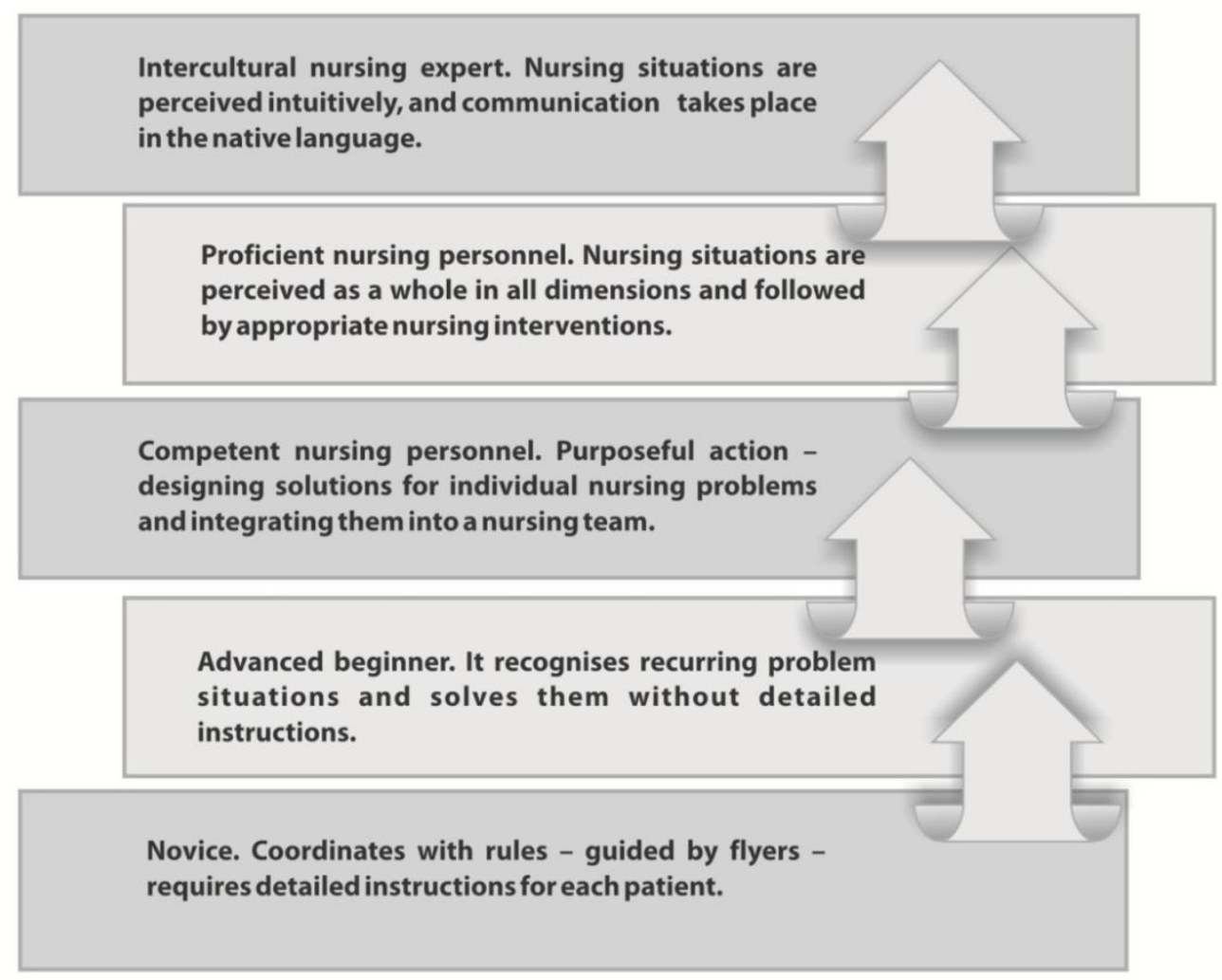

Figure 2: Intercultural competence development of German nursing personnel

An eight-module advanced training program (modulares Fortbildungsprogramm) was created in November 2014 to develop the professional intercultural competence of outpatient nursing personnel. The concept of this program was developed jointly with the nursing team. In particular, the nursing personnel was headed by a lecturer on culturally sensitive geriatric nursing who united wishes, ideas, and problems in an intercultural context. These topics included: general migration issues; conflict resolution as well as possible solutions in a multicultural team; photos of older people in different cultures; the emergence of biases and discrimination; culturally sensitive care; culturally sensitive attitude to dying and death.

Based on this, were developed a unique series of advanced training courses at the Steering Committee, and appropriate teachers were selected. The series of advanced training courses consisted of eight modules: introduction - the basis of intercultural care, language + intercultural communication (overcoming linguistic barriers), religion - Islam for care, body care in a cultural context, rituals in different cultures, types of dementia in people with a migration origin, conflict resolution in intercultural care, terminal care and attitude towards dying and death in an intercultural context. 
Each module lasted from 1.5 up to a maximum of 3 hours. The modules were independent of each other and could be visited separately. However, the goal of the project was to ensure that every nurse employee attends all modules. Nursing personnel was allowed to participate in a language course to withstand the possible language barriers between nursing personnel and patients with a migrant background. The nursing personnel developed their intercultural competences by attending other advanced training and specialized conferences in parallel with the internal series of training. Nursing personnel always had access to modern specialized literature for the development of professional intercultural competence. For this reason, the literature on intercultural care (cross-cultural care, transcultural care) was acquired and was available to nursing personnel. On the other hand, a collection of magazines and newspaper materials as well as scripts of a series of training sessions were collected during the project. Nursing personnel could always access this.

The nursing team consisted of workers with different backgrounds, and therefore it could be called "colorful". Besides, it had extensive experience of its biographical migrant origin. To develop the intercultural team professionally supervision and concomitant counseling were offered in various cases.

It should be noted that various measures developed the intercultural competence of German nursing personnel. The methodical triad of purposeful training, team support, and constant access to specialized literature were helpful. In addition to the formation of culturally sensitive knowledge and intercultural competence among workers, it is also necessary to develop the language skills of the appropriate multi-ethnic nursing personnel via additional language training (AWO Bundesverband e.V. Württemberg, 2013).

Consider the following project - the IPIKA project, "Interprofessional and intercultural activities in the area of medicine, nursing, and social services" (Interprofessionelles und Interkulturelles Arbeiten in Medizin, Pflege und Sozialdienst). It is important to emphasize that due to migration, the flow of refugees, and demographic changes, the number of patients with a migrant background in German clinics is steadily increasing. Therefore, Charite University Hospital - Berlin committed itself to provide medical care in its three central locations in Berlin. It offered a low threshold for access to medical care and treatment for many immigrants and refugee patients. Thus, there was a great need for medical personnel to develop intercultural competences to ensure the quality of medical care. The IPIKA project aims to develop the intercultural, and inter-professional capabilities of doctors, nursing personnel, and social workers. During its implementation, with the support of the Robert Bosch Foundation, within the framework of the "Operation Team" in Charité University Hospital - Berlin (Charité Universitätsmedizin), during 2016 - 2017, a series of training was developed and conducted, which consisted of five modules. One of the main directions was the care of chronically ill and polymorbid patients. As a partner of this project, along with Charite University Hospital - Berlin, namely Charite gynecological clinic, the integrated oncology center, Charité nursing sector, Charité international cooperation department, and Charite Health Academy was Alice Salomon University of Applied Sciences Berlin (ASH Berlin, 2019; Charité, 2019). 
We found out that the IPIKA advanced training program consisted of five modules (75 topics) with the following content: the relationship between migration and health, socio-cultural factors; intercultural sensitization in the professional sphere: intercultural background knowledge about chronic diseases, the role of physicians-patients-relatives; bypassing language barriers, working with translators (language and cultural mediators); conflict resolution and de-escalation in the clinic (in intercultural conditions); improvement of inter-professional cooperation and inter-professional communication; selfreflection and change of perspective. Doctors, nursing personnel, social workers, teachers, and clinical linguists from various departments and clinics in Charité attended a series of training. The IPIKA advanced training program (Fortbildungscurriculum) was of high practical importance: in particular, cultural-sensitive and interprofessional activities were practiced on the basis of prototypical clinical situations and procedures, using simulated patients (Simulationspatient) and working with professional translators. In addition, experts working in the area of counseling and care of patients with migrant backgrounds and refugee patients within and outside Charite university hospital - Berlin were involved in the modules. Participants also developed proposals for improving the care of immigrant patients in their immediate working environment, for example, by translating information about patients into several different languages, using icons, creating an intranet platform for all Charité personnel members on intercultural issues, and improving college qualifications (Charité, 2019).

Let us now turn to the IPIKA Plus project (duration of project: 2018 - 2019). The current IPIKA Plus project aims to institutionalize the content of training courses at the universities of Charite University Hospital - Berlin and Alice Salomon University of Applied Sciences Berlin. Thus, the advanced training program for the development of cross-cultural and inter-professional competences for the hospital personnel is offered at Charite Health Academy. Next, the IPIKA Plus project also carries out intercultural training and training of trainers (Interkulturelle Fortbildungen und Train-the-Trainer Einheiten) in the area of integration management (Integrationmanagement) in the nursing sector of Charité. In addition, Alice Salomon University of Applied Sciences Berlin develops a professional certification course (berufsbegleitender Zertifikatskurs) that will be available to representatives of various medical professions from the Winter Semester of the 2019/20 academic year at the Center for Advanced Training (Zentrum für Weiterbildung) at Alice Salomon University of Applied Sciences Berlin (Charité, 2019).

We should not ignore in our study the EU-funded project LEONARDO, "MIGCOMM-EU - Multilingual Intercultural Business Communication for Europe" (MIG-KOMM-EU - Mehrsprachige interkulturelle Geschäftskommunikation für Europa). The main result of this project was the Blended-Learning-Courses for business communication in German, Estonian, Latvian, Lithuanian, Romanian, Slovak, Slovenian, Czech, and Hungarian languages (EU-Projekt MIG-KOMM, 2019). 
Among them, there are Blended-Learning-Courses for medical professionals, "Blended-learning-Course Medical Communication" (Blended-learning-Kurs Medizinische Kommunikation), which can be found on the educational web portal IMED-KOMM-EU. It consists of German courses for communication with patients (die Deutschen Sprachkurse zur Patientenkommunikation), foreign doctors (Deutsch für ausländische Ärztinnen und Ärzte), and nursing personnel (Deutsch für ausländische Gesundheits- und Krankenpflegerinnen / -pfleger). These Blended-Learning-Courses are behind the photos of the main page of the web portal. "The EU funded IMED-KOMM-EU project" (Intercultural Medical Communication in Europe) was produced under the leadership of the IIK Institute for Intercultural Communication Inc. (Ansbach, Berlin, Jena, Erfurt) within the framework of the LEONARDO ITP program of the European Commission, with partners from Bulgaria, the Czech Republic, Hungary, and Slovakia. The main products of the project are five modern, interconnected Web portals and teacher's guides in German, Bulgarian, Hungarian, Slovak, and Czech, with practical modules that provide complex exercises for medical communication for doctors on the one hand and nurses on the other hand both online and offline. Later there were added exercises concerning the medical aspects of modern tourism. The modules of the courses are enhanced by private tests, podcasts/videocasts, blogs as well as links, all of which are freely accessible on the web portal. Examples of tests can be accessed by clicking the ECL button. These tests can be taken at any of our partner institutions. Additional and more in-depth information for teachers and students can be found in the special glossaries/guides on medical language (online-reference books, -dictionaries, -glossaries; books on intercultural communication, etc.)" (IMED-KOMM-EU, 2019).

By studying the issue of nursing education in the context of culture, certain theoretical studies on this topic and discussion cannot be overlooked. For example, as the first nurse theoretician, Leininger (1998) presented work on nursing theory, which integrated specific aspects of culture. In 1978, she published her second book, "Transcultural Nursing: Concepts, Theories, and Practices", in which she described the basic notions and proximity of nursing and anthropology. In theoretical assumptions, Leininger (1998) has two main concepts. On the one hand, the concept of caring for a person who divides her into general and professional care, and which varies according to culture. On the other hand, theoretically, the phenomenon of culture is significant, putting forward the traditional anthropological concept of Leininger's students Andrews and Boyle, who developed the theory and the concepts of transcultural nursing, have a different approach. Instead of the concept of culture, they put interaction in the center of their work (Domenig, 2001, p. 145; Reinhardt \& Sahmel, 2009, pp. 146-147).

Orque (1983) offers another approach to the theory of nursing. In this theory, two groups, an ethnic group or an ethnic minority and a dominant group, which has authority and power in society, are in contrast. Culture includes such areas as eating habits, linguistic and communication processes, family processes, interactive processes within the social group, art, religion, history, value 
orientations, attitudes to health, and healthy habits. For Orque (1983), the interaction between patients and their carers or nursing personnel plays a central role. Only then you can take into account the individuality of the patient and determine the specific benefits offered (Reinhardt \& Sahmel, 2009, p. 148; Visser \& de Jong, 2002, p. 103). Also, Domenig (2001) believes in his work "Professional transcultural nursing: Handbook for teaching and practice in nursing and obstetrics" that transcultural competence focuses on the interaction between nursing personnel and migrants, not culture. In essence, for them, "transcultural competence consists of the transcultural ability to interact in a migratory context" (Domenig, 2001, p. 148; Reinhardt \& Sahmel, 2009, p. 149).

The basic knowledge required for the interaction between nursing personnel and migrants relates to less experience pertaining to culture and general concepts. Domenig (2001) explains what topics or ideas she considers necessary, which we should understand as general concepts in nursing. These concepts include the concept of personality and socially oriented society, ethnomedical concept, socio-cultural ideas of health and disease, knowledge of the background of migration, knowledge of the living conditions of migrants, the connection between migration and health, accessibility and barriers to health systems, knowledge of communication and manner of expression. In addition to the knowledge gained at the cognitive level, Domenig (2001) includes the experience of nursing personnel involved with migrants. As the third element of interaction, Domenig (2001) calls empathy and understanding. The focus of intercultural learning is the understanding of foreigners. It means that we should understand, accept, and respond to foreign cultures and behaviors of people from other countries. The focus of intercultural learning is the understanding of foreigners. The aim is to understand, accept and react appropriately to foreign cultural orientations and the behavior of people from other countries (Flechsig, 2000, p. 4; Reinhardt \& Sahmel, 2009, p. 154).

There are three different levels to be taken into account when gaining transcultural competence. The first level is focusing on specific situations or contexts of care. The second level is an action that is important since the nursing personnel works independently in everyday practice, decides, and bears responsibility. The third level is the theoretical foundation of nursing interventions in a medical institution in accordance with the cultural sensitivity of individuals (Reinhardt \& Sahmel, 2009, p. 154; Uzarevich, 2001, p.6). von Bose and Terpstra (2012), in their practical book for care and communication "Caring for Muslim patients", asserted that "according to E. Kiel, transcultural competences consist of a general readiness for communication and interaction. Transcultural competences are independent key qualifications, consisting of four areas of competence: professional, social, personal, activity as well as related individual competences" (von Bose \& Terpstra, 2012, p. 16). According to Kiel (1996), transcultural competence is a fundamental skill necessary for life, work and learning in a globalized world. Ability to behave in cross-cultural situations in such a way that representatives of different cultures can openly interact and present their national culture, while each person tries to understand the positions of another. This also applies to situations of intercultural nursing, 
which is the main requirement of successful intercultural relations. A fundamental cultural sensitization is required to initiate the individual development of intercultural competence. After this sensitization, one should develop the capacity for cultural analysis. Cultural and analytical skills provide an interpretative basis for those who are interested in the true understanding of cultural aspects to understand their cultural activities and, therefore, to understand the actions of representatives of other cultures. They also allow you to harmonize a wide variety of experiences. An essential feature of the model of transcultural competence is a deep reflection of their own culture as a basis for understanding foreign cultures (Kiel, 1996).

\section{Conclusions}

Demographic changes and global migration processes have sharply put before the German nursing personnel the problem of its intercultural competence. Intercultural competence covers the concepts of multicultural, intercultural, international education, and is an important area of nursing personnel training. In the area of nursing, there are two concepts (cultural sensitivity and culturally sensitive care) in connection with intercultural competence. In the professional activity, German nursing personnel grows from beginners to nursing experts and, accordingly, its intercultural competence is developing. Currently, the development of the intercultural competence of nursing personnel is being performed in Germany through the organization of various projects and courses. They improve the interpersonal interaction at the intersection of cultures, increase the ability to work in a team, to tolerate cultural differences, to resolve intercultural conflicts and to apply intercultural knowledge in medical practice. These projects also promote the development and display of intellectual interest in other cultures, formation of intercultural literacy and intercultural interaction, the ability to tolerate relations with representatives of other cultures. Consequently, we can conclude that these advanced training projects, blendedlearning courses, on-the-job training, intercultural group training, studies of the native German personnels of both ethnic and migration backgrounds facilitate the development of its intercultural competence. The German experience in applying advanced training projects to develop the intercultural competence of nursing personnel can be interesting and valuable for use in other countries.

\section{References}

ASH Berlin. (2019). Alice-Salomon Hochschule für Sozialarbeit und Sozialpädagogik Berlin. [Alice-Salomon University of Applied Sciences]. Retrieved from https://www.ashberlin.eu/qisserver/rds?state=user\&type $=0$.

AWO Bundesverband e.V. (2014). "Pflege ist Kommunikation" Dokumentation der Abschlusstagung des ESF Projektes "FaDA" - Fachsprache Deutsch in der Altenpflege am 03.04.2014 in Berlin. ["Nursing is communication" Documentation of the final conference of the ESF project "FaDA" - German for geriatric nursing on 03.04.2014 in Berlin]. Retrieved from http://fada.awo.org/uploads/media/Bericht_zur_FaDAAbschlusstagung_vom_3.4.2014.pdf

AWO Bundesverband e.V. Württemberg. (2013). Abschlussbericht Modellprojekt: Interkulturell geöffneter Pflegedienst der AWO in Ulm [Final report Model project: Interculturally opened nursing service of the AWO in Ulm]. Retrieved from https://sozialministerium.baden-wuerttemberg.de/fileadmin/redaktion/msm/intern/downloads/Downloads_Pflege/Inno-programm-Pflege. 
Behrens, B. (2011). Interkulturelle Öffnung im Gesundheitswesen. Überblick - Strategie- Praxis [Intercultural opening in healthcare.Overview - strategy - practice.]. In R. Leiprecht, I. Petersen,W. Schulz-Kaempf (Eds.), Schriftenreihe des Interdisziplinären Zentrums für Bildung undKommunikation in Migrationsprozessen (IBKM) an der Carl von Ossietzky UniversitätOldenburg. Oldenburg, Deutschland: BISVerlag. Retrieved from https://d-nb.info/1013082893/34.

Bertelsmann, S., \& Fondazione, C. (2008). Interkulturelle Kompetenz - Die Schlüsselkompetenz im 21. Jahrhundert? [Intercultural competence - the key competence in the 21st century?]. Retrieved from https://www.bertelsmannstiftung.de/fileadmin/files/BSt/Presse/imported/d ownloads/xcms_bst_dms_30236_30237_2.pdf.

Berufs-Ausbildungs-Zentrum e.V. Selbelang. (2019). Fachkräftesicherung im Pflegebereich und zu anderen gefördeten Projekte. Kultursensible Pflege interkulturelle kompetenz [Retention of skilled labor in the area of nursing and other supported projects. Culturesensitive nursing interkulturellekompetenz]. Retrieved from https://kultursensiblepflege.de/interkulturelle_kompetenz.html.

Bundesgesetzblatt. (2017). Gesetz zur Reform der Pflegeberufe (Pflegeberufereformgesetz PflBRefG) [German nursing professions act]. Retrieved from https://www.bgbl.de/xaver/bgbl/start.xav?startbk=Bundesanzeiger_BGBl\&ju mpTo=bgbl117s2581.pdf\#_bgbl_\%2F\%2F*\%5B\%40attr_id\%3D\%27bgbl117s258 1.pdf\%27\%5D_1549966472264.

Charité - Universitätsmedizin Berlin.(2019). Aktuelles Fortbildungsprogramm: Geschäftsstelle interkulturelle Kompetenzen im Berliner Gesundheitswesen [Current advanced training programme: Office for intercultural competences in the berlin healthcare system]. Retrieved from https://interkulturellekompetenz.charite.de/projekte/ipika/ipika_plus/aktuelles_fortbildungsprogra $\mathrm{mm} /$.

Charité - Universitätsmedizin Berlin. (2019). IPIKA - interprofessionelles und interkulturelles Arbeiten in Medizin, Pflege und Sozialdienst: Geschäftsstelle interkulturelle Kompetenzen im Berliner Gesundheitswesen [IPIKA - interprofessional and intercultural work in medicine, nursing and social services: Office for intercultural competences in the Berlin healthcare system]. Retrieved from https://interkulturelle-

kompetenz.charite.de/netzwerk/ipika_interprofessionelles_und_interkulturelle s_arbeiten_in_medizin_pflege_und_sozialdienst/.

Charité - Universitätsmedizin Berlin. (2019). IPIKA: Geschäftsstelle interkulturelle Kompetenzen im Berliner Gesundheitswesen [IPIKA: Office for intercultural competences in the Berlin healthcare system]. Retrieved from https://interkulturelle-kompetenz.charite.de/projekte/ipika/.

Domenig, D. (2001). Einführung in die transkulturelle Pflege [Introduction to transcultural nursing] In D. Domenig (Ed.). Professionelle transkulturelle Pflege: Handbuch für Lehre und Praxis in Pflege und Geburtshilfe. [Professional transcultural nursing: Handbook for teaching and practice in nursing and obstetrics] (pp.148). Bern, Schweiz: Hans Huber Verlag.

Domenig, D. (2007). Transkulturelle Kompetenz: Lehrbuch für Pflege-, GesundheitsundSozialberufe [Transcultural competence: Textbook for nursing, health and social professions]. Bern, Schweiz: Hans-Huber-Verlag.

EU-Projekt MIG-KOMM. (2019). Mehrsprachige interkulturelle Geschäftskommunikation für Europa [Multilingual intercultural business communication for Europe]. Retrieved from http://www.mig-komm.eu/. 
Flechsig, K. (2000). Transkulturelles Lernen. Internes Arbeitspapier [Transcultural learning. Internal working paper] (pp. 4). Retrieved from http:/ / wwwuser.gwdg.de/ kflechs/iikdiaps2-00.htm.

Friebe, J. (2006). Migrantinnen und Migranten in der Altenpflege. Bestandsaufnahme, Personalgewinnungund Qualifizierung in Nordrhein-Westfalen: Eine Handreichung für Bildungund Praxis in der Altenpflege [Migrants in geriatric nursing. Inventory, recruitment and qualification in North Rhine-Westphalia: A guide for education and practice in geriatric nursing] (pp. 55). Bonn, Deutschland: Deutsches Institut für Erwachsenenbildung. Retrieved from https://www.diebonn.de/esprid/dokumente/doc-2006/friebe06_01.pdf.

Friebe, J., \& Zalucki, M. (Eds.). (2003) Interkulturelle Bildung in der Pflege. [Intercultural education in nursing]. Bielefeld, Deutschland: W. BertelsmannVerlag. Retrieved from https://www.die-bonn.de/esprid/dokumente/doc-2003/friebe03_01.pdf

Gesetz über die Pflegeberufe (Pflegeberufegesetz - PflBG). (2017). [German nursing professions act]. Retrieved from https://www.buzer.de/s1.htm?g=PflBG\&f=1.

Habermann, M., \& Stagge, M. (2015). Menschenmit Migrations hinter grundinder professionellen Pflege.[People with a migrant background in professional nursing]. In P. Zängl (Ed.) Zukunft der Pflege (pp. 161-175). Wiesbaden, Deutschland: Springer Verlag. https:/ / doi.org/10.1007/978-3-658-08137-9

Hellige, B., \& Michaelis, D. (2005).Handbuch für eine kultursensible Altenpflege:Curriculum Kultursensible Altenpflege [Handbook for a culture-sensitive care for the elderly: Curriculum for culture-sensitive care for the elderly]. Hannover, Deutschland: Bundesministerium für Familie, Senioren, Frauen und Jugend. Retrieved from https://www.bmfsfj.de/blob/79104/319309a6d08b82b1d933d87f9fc7bb0d/han dbuch-modul2-data.pdf.

Ilkilic, I. (2017). Interkulturelle Kompetenz als Schlüsselqualifikation für Gesundheitsberufe. [Intercultural competence as a key qualification for healthcare professionals]. G+G Wissenschaft, 2, 24-30 Retrieved from https:/ / www.grk.lifesciences-lifewriting.uni-mainz.de/files/2017/07/2017Interkulturelle-Kompetenz-als-Schlu\%CC\%88sselqualifikation-fu\%CC\%88rGesundheitsberufe.pdf.

IMED-KOMM-EU. (2019).Willkommen auf der Seite zum EU-IT-Projekt IMED-KOMM. [Welcome to the page of the EU-IT project IMED-KOMM]. Retrieved from: http://www.imed-komm.eu/.

IMED-KOMM-EU.(2019). Project description. Retrieved from http://www.imedkomm.eu/node/3.

Jürgensen, A. (2015). Sprachförderung für ausländische Pflegekräfte:Konstruktionselemente für eine Lehrgangsgestaltung in der Pflegebildung [Language support for foreign nurses: Design elements for course design in nursing education] (Master's Thesis). Katholische Hochschule Nordrhein-Westfalen, Abteilung Köln. Retrieved from https://kidoks.bsz-bw.de/frontdoor/index/index/docId/993.

Hundenborn, G., Heuel, G., Zwicker-Pelzer, R., Fendi, S., Kühn-Hempe, C., Mausolf, K., \& Scholl, H. (2018). Kultursensibilität im Gesundheitswesen: Modulhandbuch für eine kompetenzorientierte, wissenschaftsbasierte und multiprofessionelle Aus-, Fort- und Weiterbildung in der therapeutischen und pflegerischen Gesundheitsberufen [Cultural sensitivity in healthcare: Module handbook for a competence-oriented, science-based and multi-professional education, advanced and further training in the therapeutic and nursing healthcare professionals]. Katholische Hochschule Nordrhein-Westfalen. Retrieved

from https://www.mags.nrw/sites/default/files/asset/document/modulhandbuch _kultursensibilitaet_im_gesundheitswesen.pdf. 
Oldenburger, J. (2010). Pflegekräfte mit Migrationshintergrund im interkulturellen Team als Ressourse für eine erfolgreiche kultursensible Altenpflege [Nurses with a migration background in an intercultural team as a resource for successful, culture-sensitive care for the elderly]. Hamburg, Deutschland: Diplomica Verlag.

Plunkte, S. (2017). Kommunikation mit Patienten aus anderen Kulturen: Soziokulturelle Herausforderungen in der Erstversorgung [Communication with patients from other cultures: Socio-cultural challenges in primary nursing]. Monatschrift Kinderheilkunde, 165(1), 29-37. Berlin/Heidelberg, Deutschland: SpringerVerlag. Retrieved from https://link.springer.com/article/10.1007/s00112-0160169-9.

Reinhardt, A. (2009). Interkulturelle Kompetenz in der Pflege. [Intercultural competence in nursing]. In K. Sahmel (Ed.), Pflegerische Kompetenzen fördern [Promote nursing competences] (pp. 136-154). Stuttgart, Deutschland: W. Kohlhammer Verlag.

Rommelspacher, B. (2005). Transkulturelle Beratung in der Pflege. [Transcultural advice in nursing]. Retrieved from http://dg-pflegewissenschaft.de/wpcontent/uploads/2017/06/PG-4-2005-Rommelsbacher.pdf.

Uzarewicz, C. (2001). Gleitwort. In D. Domenig (Ed.). Professionelle transkulturelle Pflege: Handbuch für Lehre und Praxis in Pflege und Geburtshilfe [Professional transcultural nursing: Handbook for teaching and practice in nursing and midwifery] (pp. 6). Bern, Schweiz: Hans Huber Verlag.

Uzarewicz, C. (2002). Sensibilisierung für die Bedeutung von Kultur und Migration in der Altenpflege. Kurzbeschreibung [Sensitization of the importance of culture and migration in elderly care. Brief description]. Bonn, Deutschland: Deutsches Institut für Erwachsenenbildung. Retrieved from https://www.diebonn.de/esprid/dokumente/doc-2002/uzarewicz02_01.pdf.

Visser, M., \& de Jong, A. (2002). Interkulturelle Pflege [Intercultural nursing]. In D. Emmrich (Ed.), Kultursenitiv pflegen: Wege zu einer interkulturellen Pflegepraxis [Culturally sensitive nursing: Ways to an intercultural nursing practice] (pp. 103). München/Jena, Deutschland: Urban \& Fischer Verlag.

Von Bose, A., \& Terpstra, J. (2012). Modelle der transkulturellen und kultursensiblen Pflege [Models of transcultural and culturally sensitive nursing]. In A. von Bose, J. Terpstra (Ed.). Muslimische Patienten pflegen: Praxisbuch für Betreuung und Kommunikation. [Caring for muslim patients: Practical book for care and communication] (pp. 11-19). Berlin: Springer Verlag. https://doi.org/10.1007/978-3-642-24925-9_2.

Welk, I. (2017). Kultursensible Pflege. [Culture-sensitivecare]. CNE Schwerpunkt Multikulturelles Teamim OP, 7(4), 158-159. Retrieved from https://www.researchgate.net/publication/317867671_Kultursensible_Pfl ege.

Welt Digitale Zeitung. (2018). Zahl der Menschen mit Migrationshintergrund steigt deutlich auf 19,3 Millionen [Number of people with a migrant background rises significantly to 19.3 million]. Retrieved from https://www.welt.de/politik/deutschland/article180338680/Zahl-derMenschen-mit-Migrationshintergrund-steigt-deutlich-auf-19-3-Millionen.html.

Zanier, G. (2016). Kultursensible Pflege ist ein wechselseitiger Lernprozess [Culture-sensitive care is a mutual learning process]. Neue Caritas. Retrieved from https:/ / www.caritas.de/neuecaritas/heftarchiv/jahrgang2016/artikel/kultursensible-pflege-ist-einwechselseitiger-lernprozess. 